Diabetes and Fuel Metabolism

416

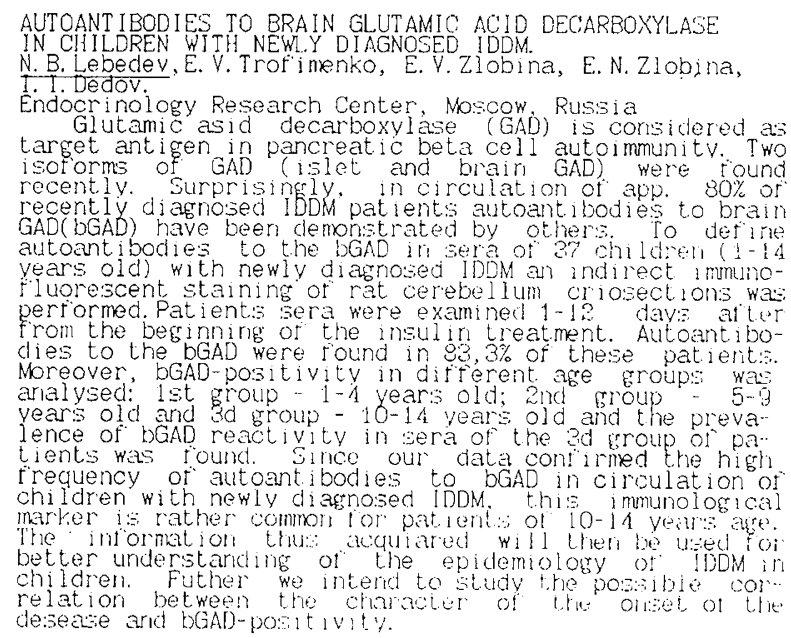

\section{* 417}

IDENTIFICATION OF A MARKER TO ENRICH POPULATIONS OF ENDOCRINE CELL PRECURSORS FROM THE HUMAN FETAL PANCREAS. A. Hayek, G.M. Beattie. M.I. Mally, T. Otonkoski, J.S. O'Brien, and F. Levine. Lucy Thorne Whittier Children's Center, The Whittier Institute, La Jolla, CA 92037, and Department of Pediatrics, University of California. San Diego, La Jolla, CA 92093-0634, USA

Isolation of the endocrine cell precursors from the human fetal pancreas is important for the understanding of islet cytodifferentiation. The progenitor cells, from which all four islet endocrine cell types arise, are present within the epithelium of the fetal pancreatic duct. Following enzymatic digestion and culture of the fetal pancreas wo obtained cell clusters resembling islets but with a high content of undifferentiated cells. Histochernical staining revealed very high acid |3-galaclosidase activity in most cells within the clusters. Alter transplantation into athymic nude inice, the clusters gave rise 10 tissue rich in differentiated endocrine cells. The histochemical finding of high acid $\beta$ galactosidase activity was confirmed by direct measurement of lysosomal enzyme aclivities. In addition, we found that the expression of acid B-galactosidase was developmentally regulated, peaking at $18-24$ weeks gestalion and declining to low levels in aduit islets. Using a fluorogenic $\beta$.galactosidase substrate, we were able to enrich for a subpopulation of cells high in acid B-galactosidase aclivity with flow cytomelry. Evidence identifying these cells as polential islet cell precursors included, besides the transplantation experiments, the colocalization in vitro of tyrosine hydroxylase, a known marker of embryonic islet cells. Thus, our results indicale that high acid $\beta$-galactosidase activity serves as a marker to enrich populations of endocrine cell precursors.

\section{9}

GENETIC INFLUENCES ON HEIGHT AND WEIGHT IN CHILDREN / ADOLESCENTS WITH TYPE-I DIABETES MELLITUS (IDDM), R.W.HOll, M.Seifert, A.Thon, M.Grabert and E. Heinze. Department of Pediatrics I, University of Ulm, D-7900 Ulm, Germany. The development of overweigit has recently been recognized as a common The development of overweigit has recently been recognized as a common growth and the prevention of overweight are major goals in pediatric diabetology. We therefore investigated, how genetic factors contribute to this undesirable event. At the time of dlagnosis, children with type-1 flabetes are tean and slightly taller than average (SD-scores: height: $+0.51 \pm 0.07$; weight: $+0.33 \pm 0.06$; BMI: $+0.08 \pm 0.05 ; n=251$, mean $\pm S E$ ). However, after $>10$ years, a significant portion of the patients loose height and become overweight: (height: $-0.16 \pm 0.08$; weight: $+0.77 \pm 0.09$, BMI: $+1.10 \pm 0.1 ; n=87$ ). In a subgroup of 156 patients ( 74 boys, 82 girls, mean age 13.5 years), girls, mean age 13.5 years), height and weight of both parents was measured at our
institution. Height-SDS was $+0.21 \pm 0.09$ for fathers and $+0.22 \pm 0.08$ for mothers. The correlation between midparental height and height-SDS in the patients $(+0.19 \pm 0.08)$ was highly significant $(r=0.41, p<0.0001)$. In contrast, patients with IDDM were considerably more overweight (SD-score: $+0.83 \pm 0.01$ ) compared to their parents $(+0.28 \pm 0.1$ for fathers and $+0.41 \pm 0.1$ for mothers $)$, and weight correlated only weakly between parents and IDDM children $(r=0.20, p<0.05)$. This correlation was significantly stronger in boys $(r=0.31, p<0.001)$ compared to girls $(r=0.10, n . s$.$) . Interestingly, in IDDM girls, the SD-score for weight increased$ slgniflcantly with age $(r=0.28, p<0.01)$, but not in boys $(r=0.18, n$.s. $)$. The age of menarche in the mothers $(13.3 \pm 0.1$ years $)$ was not different from their daughters (13.4 \pm 0.3 years). Conclusion: In IDDM girls, obesity is primarily due to factors related to the dlsease, while genetlc predispositlon plays a miner role. In contrast, with modern therapeutic regimen, stunted growth or delayed puberty is no longer a major problem, as height in IDDM children strongly refiects their genetic potential.

\section{0}

F. Chiarelli, A. Yerreut, G. Morgese

Department of Pediatrics, University of Chicti, Chicti, Italy

RELATIONSHIP BETWEEN BLOOD PRESSURE AND MICROALBUMINURIA IN ADOLESCENTS WITH TYPE 1 DIABETES MELLITUS

The aim of this study was to determine the role of increased blood pressure (BP) in the development of incipient diabetic nephropathy in the young. In 1985 we started a comprehensive program for early delection of kidncy discase in diabetic children and adolescents. This program consisted of regular neasurement of urinary albumin excretion (UAE) by RIA method (every 6 months) and BP (every 3 munths). Unsterile urine were excluded; BP was measured following the criteria of the American Academy of Pediatrics. Glycemic and metabolic control was assessed every 3 months by measuring HbAlc, serum cholesterol and triglycerides. During the follow-up 11 adolescents and young adults (age 14-22 $\mathrm{yr}$, duration of diabetes 9.3-19.7 yr) developed persistent microalbuminuria, defined as UAE greater than $30 \mathrm{ug} / \mathrm{min} / 1.73 \mathrm{~m}^{2}$ in at least two out of three consecutive measurements; at the beginning of the study these patients had UAE and BP in the normal rangc (UAE: 5-12 $\mathrm{ug} / \mathrm{min} / 1.73 \mathrm{~m}^{2}$; systolic BP: $108-123 \mathrm{mmHg}$; diastolic BP: 70-82 mmHg). Diabetics with microalbuminuria had normal systolic and diastolic BP during the first year of UAE persistingly
in the microalbuminuric range. A significant increase of both systolic and diastolic BP became in the microalbuminuric range. A signiticant increase of both systelic and diastolic BP became evident during the fourth year of persistent microalbuminuria. Microalbuminuric diabetics had poorer long-term glycemic control than normoalbuminuric patients (matched for sex, age and duration of diabetes)(7-ycar HbAlc $9.2 \pm 1.3$ vs. $8.3 \pm 1.2 ; \mathrm{p}<0.03$ ); serum cholesterol was higher in diabetics with microalbuminuria. Increase of $\mathrm{BP}$ seems to develop after that persistent of clinical diabetic nephropathy and end-stage renal failure.

\section{* 418}

NICOTINAMIDE AND INTERLEUKIN-1 (IL-1) EFFECTS ON HUMAN PANCREATIC ISLET FUNCTION. U. ZUMSTEG M Brendel, R. Alejandro and J. Nerup, Steno Diabetes Center, 2820 Gentofte, Denmark and Diabetes Research institute, University of Miami, Miami, FL 33101, USA

The cytokine IL-1 B inhibits rodent B-cell function in a time- and dose-dependent manner and has been implicated as effector molecule in the IDDM pathogenesis. In isolated rat islets IL-1 toxicity to B-cells is dependent on generation of free nitric oxide radicals. Nicotinamide (NA), a free radical scavenger and inhibitor of poly-ADP-ribose synthetase prevents macrophage mediated islet cell destruction and autoimmune diabetes in the NOD mouse, and NA shows promising preventive effects in prediabetic humans. Here we studied IL-1 sensitivity and NA protection of isolated human isiets using a completely intra-species in vitro system: A $24 \mathrm{hr}$ human islet exposure to authentic recombinant human $\mathrm{IL}-1 \mathrm{~B}$ $(150 \mathrm{pg} / \mathrm{ml})$ reduces $16.7 \mathrm{mM}$ glucose-chailenged islet insulin release to $0.19 \pm 0.08 \mathrm{ng} /$ islet/2hrs vs $0.41 \pm 0.14$ in controls $(\mathrm{p}<0.05)$. Coincubation with $10 \mathrm{mM}$ NA counteracts the $\mathrm{IL}-1$ effect to $0.38 \pm 0.13 \mathrm{ng} / \mathrm{s}$ slet/2hrs (ns vs controls) without showing any intrinsic effect on $B$-cell function by itself. A $6 \mathrm{hr}$ human islet IL-1 exposure already leads to a $30 \%$ decrease of insulin accumulation while in rat islets functional inhibition is seen only after 24 hrs of $\mathrm{lL}-1$ exposure. In conclusion isolated human islets are most sensitive to $\mathrm{IL}-1$ induced $B$-cell suppression and NA protects human islet function against the IL-1 attack.

\section{1} PRORENIN (PR) AND DIABETIC NEPHROPATHY (DN): A STUDY OF
ADOLESCENTS WITH IDDM AND THEIR SIBLINGS. D Dincmin, JW Balfe, C Crompton, E Sochett, A Chatzilias, B Cotter, D Ostrond, Depts of Pediatrics ind Crompton, E Sochett, A Chatzilias, B Cotter, D Ostmond, Depts of Pediatrics ind
Physiology, Univ of Toronto, Hosp for Sick Children, 'Toronto, Canada M.5G IX8. Physiology, Univ of Toronto, Hosp for Sick Children, 'Toronto, Canada MSG IX8.
We wished to study (i) in IDDM adolescents, the relationship of plasma PR We wished to study (i) in IDDM adolescents, the relationship of plasma PR
concentrations, measured by dircect monoclonal antibody assay, to the presence of concentrations, measured by direct monoclonal antibody assay, to the presence of
microalbuminuria (MA), BP and metabolic control ( $\mathrm{HbAlc}$ ); and (ii) whether PR microalbuminuria (MA), BP and metabolic control (HbAlc); and (ii) whether PR
levels differ in siblings of IDDMs with and without MA. To do this, we measured PR levels differ in siblings of IDDMs with and without MA. To do this, we measured PR
concentrations in (a) IDDM adolescents with MA $(n=25)$; (b) an IDDM group concentrations in (a) IDDM adolescents with MA ( $n=25$ ); (b) an IDDM group
without MA (nonMA, $n=25$ ) matched for age, sex, discase duration, and BMI; and without MA (nonMA, $n=25$ ) matched for age, sex, discase duration, and BMI; and
(c) the nondiabetic siblings of these 2 groups $(n=38)$. Of the BP measures, only (c) the nondiabetic siblings of these 2 groups $(n=38)$. Of the BP measures, only
diastolic BP was significantly higher in the MA group $(59+6$ vs $55+6 \mathrm{~mm} \mathrm{Hg}$, diastolic BP was significantly higher in the MA group $(59 \pm 6$ vs $55 \pm 6 \mathrm{~mm} \mathrm{Hg}$,
$\mathrm{p}<0.03)$. PRs were significantly greater in the MA compared to nonMA group $p<0.03)$. PRs were significantly greater in the MA compared to nonMA group
$(226 \pm 68$ vs $168 \pm 50 \mathrm{pg} / \mathrm{ml} 1, \mathrm{p}<0.0001)$, being higher in $23(92 \%)$ of the $25 \mathrm{MA}$ $(226 \pm 68$ vs $168 \pm 50 \mathrm{pg} / \mathrm{mll}, \mathrm{p}<0.0001)$, being higher in $23(92 \%)$ of the $25 \mathrm{MA}$
members of the matched pairs. In the MA group, PR showed an inverse correlation members of the matched pairs. In the MA group, PR showed an inverse correlation
with current $\mathrm{HbA} 1 \mathrm{c}(\mathrm{r}=-0.50, \mathrm{p}<0.01)$, but no relationship to IDDM duration, disease mean HbAlc or BP in either IDDM group. PR concentrations in the IDDMs were significantly greater than in their nondiabetic siblings $(197 \pm 67$ vs $135 \pm 50$ $\mathrm{pg} / \mathrm{ml}, \mathrm{p}<0.0001)$. Also, siblings of MA IDDMs had significantly higher PRs than those of nonMA IDDMs (158 $\pm 56 \mathrm{vs} 115 \pm 32 \mathrm{pg} / \mathrm{ml}, \mathrm{p}<0.001)$. In summary, PR concentrations (i) were greater in most IDDM adolescents with MA compared to matched nonMA IDDMs and may serve as an indicator of incipient DN; (ii) were significantly higher in IDDMs compared to their siblings; and (iii) were higher in the siblings of those IDDMs with than those without MA. These data suggest that plasma PR concentrations may be affected by factors related both to diabetes itself (metabolic control) as well as to the presence of DN. Further there may be in important genetic component to PR concentrations, and thus to DN. 